\title{
Response of advance regeneration to intensity of harvest and fertilization on boreal wetlands
}

\author{
by Y. Teng ${ }^{1}$, S.E. Bailey ${ }^{2}$, N.W. Foster ${ }^{3}$ and P.W. Hazlett ${ }^{3}$
}

Post-harvest nutrient status and growth of understory black spruce (Picea mariana [Mill.] B.S.P.) advance regeneration during the first seven years after harvest with advance regeneration protection (HARP) was evaluated on two boreal wetlands in northeastern Ontario. Three intensities of HARP were investigated: light, medium and heavy, corresponding to 35, 50, 100\% basal area removal of merchantable trees. Limiting nutrients were diagnosed with a nitrogen $(\mathrm{N})$, phosphorus $(\mathrm{P})$ potassium $(\mathrm{K})$ fertilization trial. Release by HARP significantly improved foliar N by $43-214 \%$, and $\mathrm{P}$ by $40-317 \%$, stimulated needle mass by $13-114 \%$ and annual height increment of spruce by $6-50 \%$ on all three HARP treatments. Growth of spruce was statistically greater after heavy release than the other two HARP treatments by the sixth year. Fertilization with a combination of $\mathrm{N}$ and $\mathrm{P}$ further increased needle biomass and height increment by $23-46 \%$ and $16-26 \%$, respectively. Nitrogen and, secondly, $\mathrm{P}$ were limiting for rapid natural reestablishment of black spruce stands on boreal peatlands.

Keywords: black spruce, nitrogen, phosphorus, potassium, clearcut

Le niveau des éléments nutritifs et la croissance après la récolte pour la régénération pré-établie en sous-étage d'épinette noire (Picea mariana [Mill.] B.S.P.) au cours des sept premières années après la récolte avec protection de la régénération pré-établie (HARP) ont été évalués sur deux sites humides boréaux du nord-est de l'Ontario. Trois intensités de HARP ont été étudiées : légère, moyenne et forte, correspondant à 35, 50 et $100 \%$ de coupe de la surface terrière des tiges marchandes. Les éléments nutritifs primordiaux ont fait l'objet d'un diagnostique lors d'une fertilisation à base d'azote $(\mathrm{N})$, de phosphore $(\mathrm{P})$ et de potassium $(\mathrm{K})$. Le dégagement suite à la HARP a amélioré de façon significative la quantité de $\mathrm{N}$ foliaire de 43 à $214 \%$ et de $\mathrm{P}$ de 40 à $317 \%$, a stimulé la masse foliaire de 13 à $114 \%$ et l'accroissement annuel en hauteur des épinettes de 6 à $50 \%$ dans les trois traitements HARP après six ans. La fertilisation avec un mélange de $\mathrm{N}$ et de $\mathrm{P}$ a augmenté encore plus la biomasse foliaire et la croissance en hauteur de 23 à $46 \%$ et de 16 à $26 \%$ respectivement. L'azote, et en second, le $\mathrm{P}$ ont été déterminants pour un rétablissement naturel rapide des pessières noires dans les tourbières boréales.

Mots-clés: épinette noire, azote, phosphore, potassium, coupe à blanc

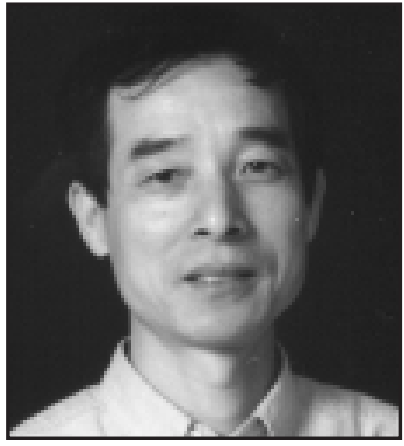

Y. Teng

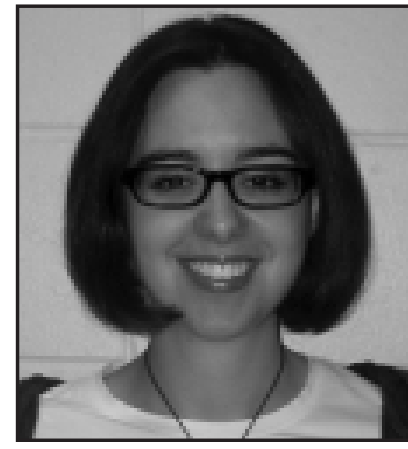

S.E. Bailey

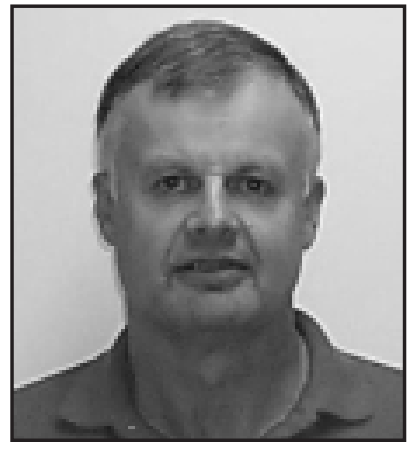

N.W. Foster

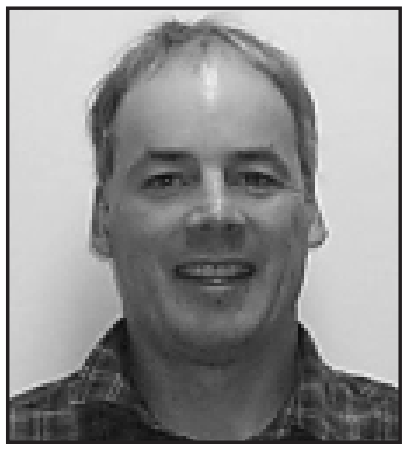

P.W. Hazlett

\section{Introduction}

On peat soils in eastern Canada, productive, well-stocked, uneven-aged, black spruce (Picea mariana [Mill.] B.S.P.) stands have developed from advance regeneration after handfelling with horse-skidding (Paquin et Doucet 1992) in a shorter period than seed-origin stands (Morin and Gagnon 1992). Harvest with advance regeneration protection (HARP), therefore, is attractive because of its low cost and because sites can be considered regenerated immediately after harvest, with

${ }^{1}$ Faculty of Forestry, University of Toronto, Toronto, ON M5S 1A1. E-mail: yuanxin.teng@utoronto.ca.

${ }^{2}$ Lake Abitibi Model Forest, Box 129 Cochrane, ON P0L 1C0.

${ }^{3}$ Natural Resources Canada-Canadian Forest Service, 1219 Queen St. E., Sault Ste. Marie, ON P6A 2E5. E-mail: nfoster@NRCan.gc.ca

no further treatment or expenditure required (Groot 1995). MacDonell and Groot (1996) confirmed that a complete mechanical removal of all merchantable stems $(>10 \mathrm{~cm} \mathrm{dbh})$ from second-growth stands in wetlands left sufficient residual trees for regeneration. In these semi-closed ecosystems, post-harvest nutrient loss from the system by leaching and lateral movement is unlikely. If increased post-harvest available nutrients cannot be promptly used by desirable trees such as black spruce, however, growth of unwanted, fast-growing shrub species (Alnus, Salix, Rubus) may be stimulated, thus changing succession patterns of the ecosystem (Brumelis and Carleton 1988, 1989) and causing the retardation of black spruce regeneration.

This study examines the effect of mechanical HARP on nutrient response and growth of surviving, understory black spruce 
regeneration during the first seven years after release, and limiting nutrients(s) before and after release. Various degrees of release by HARP were compared to determine the logging intensity that would best stimulate the nutrition and growth of advance regeneration (with least impact of nutrient resources) in wetland black spruce forests. Post-harvest nutritional limitation was assessed by vector analysis (Timmer 1991, Haase and Rose 1995) and was confirmed by a parallel fertilization trial on a similar experimental site. Vector analysis has been applied with success to detect deficient nutrients and fertilization response in Larix leptolepis [Sieb. and Zucc.] Gord. in Newfoundland (Wells 1991), Pinus contorta Dougl. in interior British Columbia (Weetman and Fournier 1982) and Picea mariana in the Ontario Claybelt (Munson and Timmer 1989).

\section{Study Area}

The study was conducted as a part of the Lake Abitibi Model Forest (LAMF) program (Anon. 1996). The experimental sites (lat. $49^{\circ} 00^{\prime} \mathrm{N}$; long. $81^{\circ} 30^{\prime} \mathrm{W}$ ) were located north-east of Cochrane, Ontario, Canada, within the Great Northern Claybelt of the boreal forest. Mean annual precipitation of the area (Cochrane) is $885 \mathrm{~mm}$; the average January and July temperatures are -18 and $17^{\circ} \mathrm{C}$, respectively (Atmospheric Environment Service 1982a, b). The HARP experimental site was occupied by uneven-aged second-growth black spruce stands, with $35-75 \mathrm{~cm}$ of peat over fine- to medium-textured glaciolacustrine deposits of glacial Lake Barlow-Ojibway (lacustrine clay). The site was classified as predominantly (75\%) Ecosite 12 (Alnus-herb poor) with scattered ES11 (Ledum) and ES13 (Alnus-herb rich) inclusions (Taylor et al. 2000). The peat soil was acidic with $\mathrm{pH}$ ranging from 3.7 to 4.8 . Total nitrogen $(\mathrm{N})$ concentration of the peat ( $1.03 \%$ to $1.59 \%$ ) falls into the low end of published ranges (Brumelis and Carleton 1988) so that the $\mathrm{C}: \mathrm{N}$ ratio was high (37 to 46:1). Mean dbh, total basal area and volume of the stand were $7.6 \mathrm{~cm}, 29.6 \mathrm{~m}^{2} \mathrm{ha}^{-1}$ and $120 \mathrm{~m}^{3}$ ha $^{-1}$, respectively (Teng et al. 1996). The numbers of merchantable trees $(\mathrm{dbh}>10 \mathrm{~cm})$ and unmerchantable trees (height $>1.3 \mathrm{~m}$ with stem $\mathrm{dbh}<10 \mathrm{~cm}$ ) were 1500 and 4170 stems ha $^{-1}$, respectively, indicating full stocking of the stands. The advance regeneration (seedlings and layers, height $<1.3 \mathrm{~m}$ ) was abundant ( 25000 stems ha $^{-1}$ ) before harvest.

The fertilized site consisted of over-mature black spruce with equal dominance of ES 11 and ES 12 and scattered ES 13 inclusions, with a pre-harvest density of trees $>1.3 \mathrm{~m}$ in height averaging 3367 stems ha- and basal area averaging $20 \mathrm{~m}^{2} \mathrm{ha}^{-1}$, with an average height of $19.5 \mathrm{~m}$, and with a peat depth of $60-100 \mathrm{~cm}$ (MacDonell and Groot 1997).

\section{Methods and Materials}

\section{Harvesting with Regeneration Protection (HARP)}

Details of the harvest treatments were given by MacDonell and Groot (1996). Briefly, stem-only careful logging (HARP) was conducted using a cut-to-length system, single grip harvester (Timberjack FMG 1270) and a forwarder (Timberjack FMG 1010) during January to March of 1994. Four levels (control, light, medium and heavy) cutting, i.e., 0, 35, 50, 100\% basal area removal of merchantable trees were applied in triplicate to 3.75 -ha $(250 \times 150 \mathrm{~m})$ plots.

In each plot, three $10 \times 10$-m subplots were established. Ten advance regeneration spruce from each subplot, 20 to $60 \mathrm{~cm}$ in height, were tagged and measured for total height and lead- er length in mid-October of 1994 to 2000 (90 spruce/treatment). The spruce were selected so that their initial average heights were not significantly different among harvesting treatments. Foliar samples from each tagged tree were collected in the fall of each year until 1998 and oven-dried at $70^{\circ} \mathrm{C}$ for 48 hours to derive mean needle dry mass. Subsamples were ground for chemical analysis. Nitrogen was determined using a Tecator 1030 Analyzer after semimicro-Kjedahl digestion. Analysis of phosphorus $(\mathrm{P})$, potassium $(\mathrm{K})$, calcium $(\mathrm{Ca})$, and magnesium $(\mathrm{Mg})$ was done by a Thermo Jarrel-Ash ICAP 1100 Spectrometer after wet ashing with nitric-perchloric acids. Significance of spruce responses in height increment and needle dry mass to harvesting treatments were evaluated by analysis of variance (ANOVA) for a completely randomized design using SAS statistical software (SAS Institute 1985). The needle dry mass and chemical composition were interpreted using vector analysis to detect the most limiting or responding nutrient(s) and possible nutritional interactions involved.

\section{Fertilization Experiment}

To confirm the diagnosis of limiting nutrient(s) in black spruce wetlands, a NPK fertilization experiment was carried out after harvesting with advance regeneration protection using the cutto-length system (single grip harvester) with delimbing on site (heavy release). The experiment was a completely randomized factorial with two levels ( 0 and $200 \mathrm{~kg}$ element $\mathrm{ha}^{-1}$ ) of three factors $\left(\mathrm{N}, \mathrm{P}\right.$ and $\mathrm{K}$ ) applied as $\mathrm{NH}_{4} \mathrm{NO}_{3}, \mathrm{Ca}\left(\mathrm{H}_{2} \mathrm{PO}_{5}\right)$ and $\mathrm{KCl}$ with four replications. Seven black spruce of height of 20-60 $\mathrm{cm}$ were randomly selected from each of 32 mini-plots $(20 \times$ $20 \mathrm{~m}$ ) (28 spruce/treatment). The initial average heights of the selected spruce (mean $31.3 \mathrm{~cm}$, S.D. $4.8 \mathrm{~cm}$ ) were statistically similar between treatments. The uniformity in spruce response to treatment within the experimental area was evaluated by ANOVA for a randomized complete block design. The fertilizers were topdressed within an area of $1 \mathrm{~m}^{2}$ around each of the seven trees per plot in early June, 1994. The trees were tagged and their height was measured at the time of fertilization. At the end of the growing season in mid-October of 1994-2000, tree height and leader length were measured and first whorl foliar samples were collected (1994-1998). Foliar samples from each mini-plot were composited for chemical analysis before treatment and analyzed by the same procedure as above. Significance of treatment and time and their interactions on height increment and needle mass were analyzed by ANOVA for a completely randomized design, respectively, using SAS (SAS Institute 1985). A multiple range test (Tukey) was used to test for differences among treatments. Vector analysis was applied to foliar mass and chemical composition data from October 1994

\section{Results and Discussion Growth Response}

According to the ANOVA results, there were significant differences among harvest treatments, years, and treatment $\times$ year interaction for needle mass and height increment (Table 1). Analysis of current needles after the first year indicated that mass was increased by 14,30 and $13 \%$, respectively, by light, medium and heavy harvest (Fig. 1). By the fourth year after release, average needle mass associated with the heavy treatment was statistically greater than that on light and medium harvesting treatments and remained larger until the end of the study $(\mathrm{p}<0.05$; Fig. 1). 
Table 1. Analysis of variance for height increment and needle mass of black spruce advance regeneration by treatment and sampling year after release or release and fertilization in the spring of 1994

\begin{tabular}{|c|c|c|c|c|c|}
\hline Dependent variable & Source & df & MS & $\mathbf{F}$ & $\mathbf{P}$ \\
\hline $\begin{array}{l}\text { Height } \\
\text { increment }\end{array}$ & $\begin{array}{l}\text { Year } \\
\text { Harvest } \\
\mathrm{Y} \times \text { Harvest } \\
\text { Error }\end{array}$ & $\begin{array}{r}6 \\
3 \\
18 \\
2376\end{array}$ & $\begin{array}{r}289.510 \\
1067.581 \\
94.253 \\
10.367\end{array}$ & $\begin{array}{r}27.93 \\
102.98 \\
9.09\end{array}$ & $\begin{array}{l}0.0001 \\
0.0001 \\
0.0001\end{array}$ \\
\hline Needle mass & $\begin{array}{l}\text { Year } \\
\text { Harvest } \\
\text { Y } \times \text { Harvest } \\
\text { Error }\end{array}$ & $\begin{array}{r}4 \\
3 \\
12 \\
136\end{array}$ & $\begin{array}{l}0.657 \\
0.912 \\
0.091 \\
0.031\end{array}$ & $\begin{array}{r}21.48 \\
29.81 \\
2.97\end{array}$ & $\begin{array}{l}0.0001 \\
0.0001 \\
0.0010\end{array}$ \\
\hline $\begin{array}{l}\text { Height } \\
\text { increment }\end{array}$ & $\begin{array}{l}\text { Year } \\
\text { Fertilization } \\
\mathrm{Y} \times \mathrm{F} \\
\text { Error }\end{array}$ & $\begin{array}{r}6 \\
7 \\
42 \\
1422\end{array}$ & $\begin{array}{r}92.574 \\
99.944 \\
19.778 \\
8.527\end{array}$ & $\begin{array}{r}10.86 \\
11.72 \\
2.32\end{array}$ & $\begin{array}{l}0.0001 \\
0.0001 \\
0.0001\end{array}$ \\
\hline Needle mass & $\begin{array}{l}\text { Year } \\
\text { Fertilization } \\
\mathrm{Y} \times \mathrm{F} \\
\text { Error }\end{array}$ & $\begin{array}{r}4 \\
7 \\
28 \\
120\end{array}$ & $\begin{array}{l}0.988 \\
0.154 \\
0.017 \\
0.0205\end{array}$ & $\begin{array}{r}48.07 \\
7.49 \\
0.83\end{array}$ & $\begin{array}{l}0.0001 \\
0.0001 \\
0.7072\end{array}$ \\
\hline
\end{tabular}

Note: Mean squares are based on type III sums of squares.

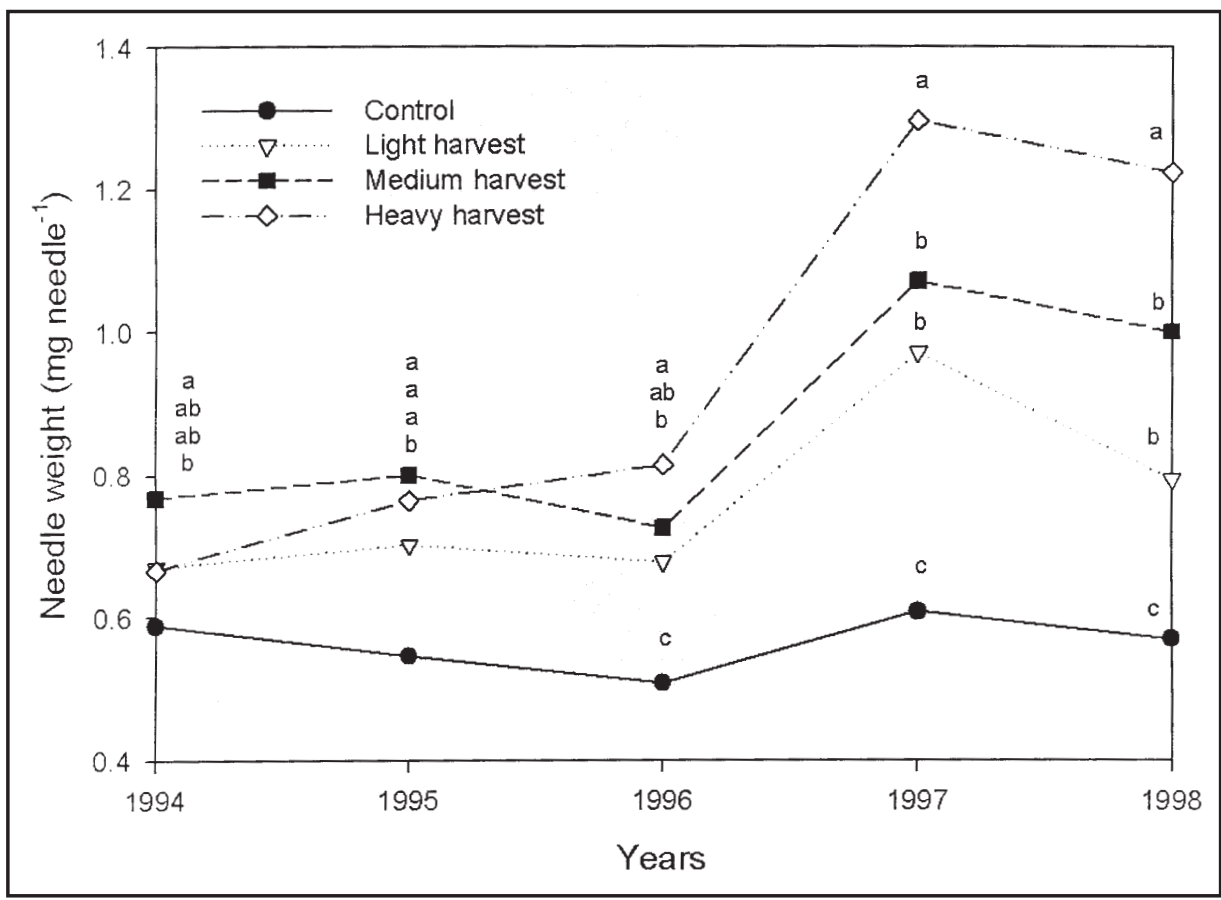

Fig. 1. Mass (mg/needle) of black spruce foliage $(n=100)$ from understory advance regeneration after different intensities of harvest in 1994. Data points with the same letter are not significantly different $(\mathrm{p}<0.05$; $\mathrm{n}=4)$.

During the first two post-harvest growing seasons (1994-1995), there was no difference in height among harvest treatments and control (Fig. 2). Usually there is delay in growth response to overstory removal as layers have a long acclimation period with maximum height growth not attained until 20 to 30 years after release (Pothier et al. 1995, Paquin et al. 1999). The three harvesting treatments became statistically different from the control during the fourth year after release ( $<<0.05$; Fig. 2 ). The heavy harvest treatment produced the maximum advance regeneration heights and became statistically larger in 1999 and 2000 (sixth and seventh year after release) than the other two harvest treatments ( $\mathrm{p}<0.05$; Fig. 2). In other ecosystems, Engelmann spruce (Picea engelmannii) height growth response has been reported (McCaughey and Schmidt 1982) to be propor- tional to the removal of overstory trees. Recent studies in black spruce cutovers have shown that release by HARP had positive effects on the growth of black spruce advance regeneration (Doucet et Boily 1986, Paquin et Doucet 1992).

Growth of the released advance regeneration at the LAMF experimental site was stimulated further by fertilization (Table 1). According to the ANOVA results, there were significant differences among fertilization treatments and years for needle mass and height increment. Treatment $\mathrm{x}$ year interaction was significant for increment, but not for needle mass. Nitrogen in combination with both $\mathrm{P}$ and $\mathrm{K}$ produced significantly greater needle weights in the first year following fertilization. Phosphorus had a consistent positive effect on needle mass (Table 2). Nitrogen and $\mathrm{P}$ fertilizers in combination 


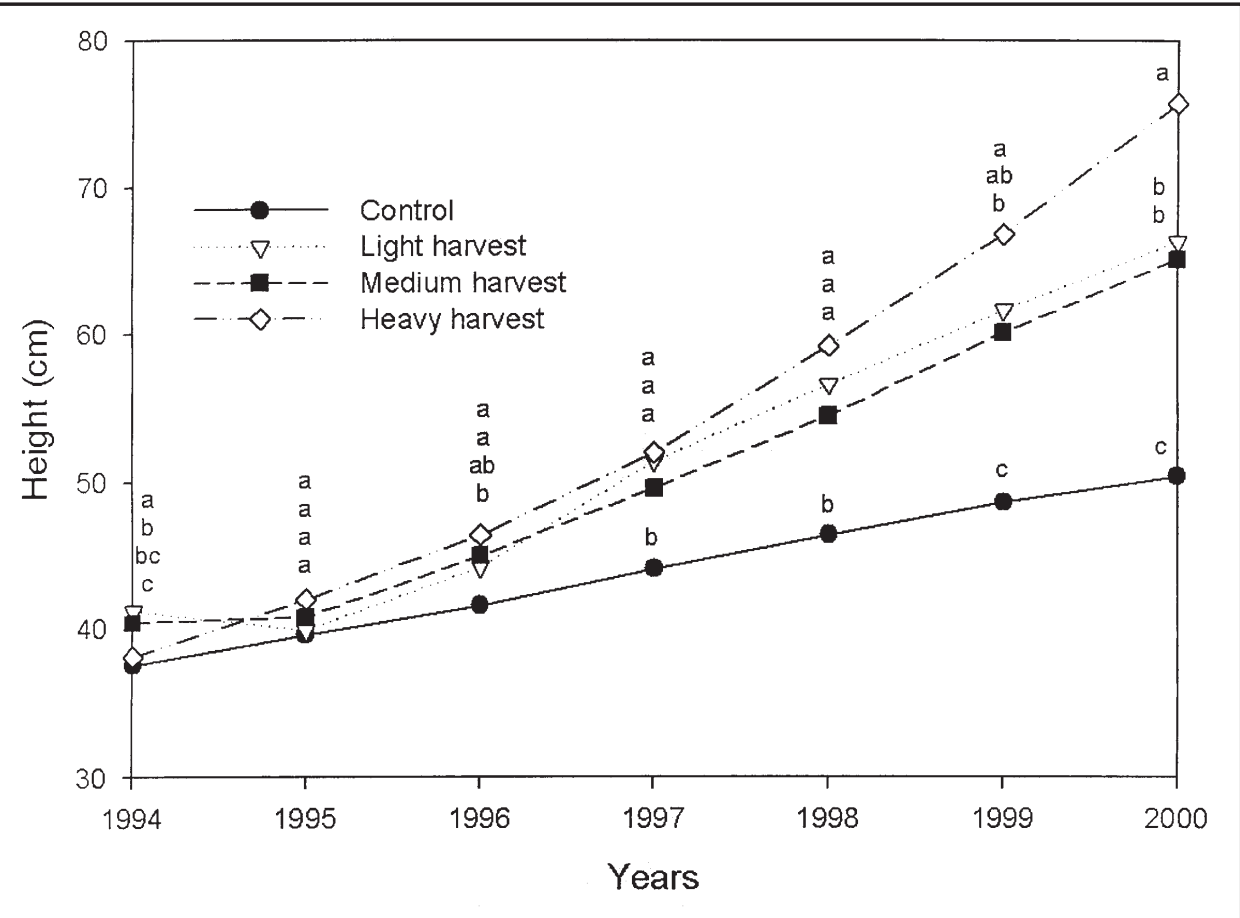

Fig. 2. Height (cm) in October of understory black spruce advance regeneration after different intensities of harvest in 1994. Data points with the same letter are not significantly different $(\mathrm{p}<0.05 ; \mathrm{n}=4)$.

Table 2. Changes, by treatment and sample year, in the mass $\left(\mathrm{mg}\right.$ needle $\left.\mathrm{e}^{-1}\right)$ of black spruce foliage $(\mathrm{n}=100)$ from understory advance regeneration released and fertilized in the spring of 1994 . Means followed by the same letter in columns are not statistically different $(p<0.05 ; n=4)$

\begin{tabular}{|c|c|c|c|c|c|}
\hline Treatment & 1994 & 1995 & 1996 & 1997 & 1998 \\
\hline Control & $0.57 \mathrm{a}$ & $0.72 \mathrm{a}$ & $0.70 \mathrm{a}$ & $0.85 \mathrm{a}$ & $0.90 \mathrm{a}$ \\
\hline $\mathrm{N}$ & $0.66 \mathrm{ab}$ & $0.78 a b c$ & $0.70 \mathrm{a}$ & $0.90 \mathrm{a}$ & $1.12 \mathrm{ab}$ \\
\hline $\mathrm{P}$ & $0.66 \mathrm{ab}$ & $0.93 \mathrm{c}$ & $0.74 \mathrm{ba}$ & $1.02 \mathrm{ab}$ & $1.25 \mathrm{~b}$ \\
\hline K & $0.56 \mathrm{a}$ & $0.70 \mathrm{a}$ & $0.70 \mathrm{a}$ & $0.87 \mathrm{a}$ & $0.95 \mathrm{a}$ \\
\hline NP & $0.83 \mathrm{~b}$ & $0.95 \mathrm{c}$ & $0.86 \mathrm{~b}$ & $1.20 \mathrm{~b}$ & $1.26 \mathrm{~b}$ \\
\hline PK & $0.53 \mathrm{a}$ & $0.95 \mathrm{c}$ & $0.68 \mathrm{a}$ & $0.99 \mathrm{ab}$ & $1.03 \mathrm{ab}$ \\
\hline NK & $0.77 \mathrm{~b}$ & $0.78 \mathrm{abc}$ & $0.64 \mathrm{a}$ & $0.93 \mathrm{a}$ & $1.09 \mathrm{ab}$ \\
\hline NPK & $0.68 \mathrm{ab}$ & $0.81 \mathrm{abc}$ & $0.69 \mathrm{a}$ & $1.04 \mathrm{ab}$ & $1.02 \mathrm{ab}$ \\
\hline
\end{tabular}

Table 3. Changes, by treatment and sample year, in the height increment $(\mathrm{mm})$ of understory black spruce advance regeneration after release and fertilization in the spring of 1994. Means followed by the same letter in columns are not statistically different $(p<0.05 ; n=4)$

\begin{tabular}{|c|c|c|c|c|c|c|c|}
\hline Treatment & 1994 & 1995 & 1996 & 1997 & 1998 & 1999 & 2000 \\
\hline Control & $21 \mathrm{ab}$ & $16 \mathrm{a}$ & $31 \mathrm{a}$ & $28 \mathrm{a}$ & $29 \mathrm{a}$ & $37 \mathrm{a}$ & $33 \mathrm{ab}$ \\
\hline $\mathrm{N}$ & $26 \mathrm{bc}$ & $50 \mathrm{~b}$ & $41 \mathrm{abc}$ & $24 \mathrm{a}$ & $21 \mathrm{a}$ & $30 \mathrm{a}$ & $27 \mathrm{a}$ \\
\hline $\mathrm{P}$ & $22 \mathrm{ab}$ & $28 \mathrm{a}$ & $45 \mathrm{bcd}$ & $35 \mathrm{ab}$ & $36 \mathrm{ab}$ & $37 \mathrm{a}$ & $34 \mathrm{ab}$ \\
\hline K & $20 \mathrm{a}$ & $18 \mathrm{a}$ & $32 \mathrm{ab}$ & $32 \mathrm{ab}$ & $35 \mathrm{ab}$ & $43 \mathrm{a}$ & $37 \mathrm{ab}$ \\
\hline NP & $30 \mathrm{c}$ & $68 \mathrm{c}$ & $57 \mathrm{~d}$ & $51 \mathrm{c}$ & $45 \mathrm{~b}$ & $45 \mathrm{a}$ & $31 \mathrm{ab}$ \\
\hline PK & $18 \mathrm{a}$ & $21 \mathrm{a}$ & $52 \mathrm{~cd}$ & $45 \mathrm{bc}$ & $45 \mathrm{~b}$ & $48 \mathrm{a}$ & $42 \mathrm{ab}$ \\
\hline NK & $28 \mathrm{c}$ & $45 \mathrm{~b}$ & $39 \mathrm{abc}$ & $34 \mathrm{ab}$ & $31 \mathrm{ab}$ & $41 \mathrm{a}$ & $28 \mathrm{a}$ \\
\hline NPK & $28 \mathrm{c}$ & $62 c$ & $54 \mathrm{~cd}$ & $56 \mathrm{c}$ & $46 \mathrm{~b}$ & $48 \mathrm{a}$ & $45 \mathrm{~b}$ \\
\hline
\end{tabular}

produced significantly higher $(23-46 \%)$ needle mass throughout the entire study period ( $\mathrm{p}<0.05$; Table 2). Watt (1967) also found a combination of $\mathrm{N}$ and $\mathrm{P}$ produced the heaviest foliar weight in black spruce and was maintained for the three years of his study.

The advance regeneration responded significantly in terms of annual height increment to $\mathrm{N}$ addition (Table 3). By the third year after release, increased growth was observed only with $\mathrm{P}$ treatments. The combination of NP, PK and NPK produced the best height increment growth (Table 3). Six years after fertilization, although the PK and NPK fertilization treatments maintained height increments $30 \%$, higher than the control, there were no statistically significant differences between treatments (Table 3). A previous study by Paquin et al. (1998) showed a similar result with a significant height increase following the second year after NPK fertilization that remained throughout the rest of their five-year study. The response of mature black spruce wetland and upland stands in Ontario's Great Northern Claybelt to NPK fertilization, likewise, has been modest and short-lived (Weetman et al.1987, Morrison 1991).

There were statistically significant differences in black spruce height increment $(\mathrm{p}<0.0001)$ response to treatments across the experimental area chosen for fertilization (block and treatment $\times$ block effects). According to the ANOVA results 
(not shown) the block effect was significant only in 1994 and 1995. Alder (Alnus rugosa) density was not uniform within the experimental area, which was divided into four blocks, two with high and two with low alder density. The multiple range test among blocks showed that the better shoot development responses to fertilization were observed in the Ledum-dominated (non-alder) blocks. Better growth may be explained by less competition for $\mathrm{N}$ with fast-growing alder within blocks dominated by Ledum. Alder presence also created soil conditions (lower $\mathrm{C}: \mathrm{N}$ ratio in peat) that were more favourable for $\mathrm{N}$ turnover in the soil (Bhatti et al. 1998).

\section{Nutritional Response}

The increase of needle mass in all harvest treatments was associated with significant increases in $\mathrm{N}$ and $\mathrm{P}$ contents (Fig. 3a and $3 \mathrm{~b}$ ). Initially, there was a non-significant decrease in foliar $\mathrm{K}$ in the light and heavy harvest (Fig. 3c). However, by the third year after the cut, the heavy harvest treatment had significantly higher $\mathrm{N}, \mathrm{P}$ and $\mathrm{K}$ foliar contents $(\mathrm{p}<0.05$; Fig. 3 ) than the control. Van Cleve et al. (1990) found that an increase in soil temperature increased black spruce needle mass and also noted generally higher $\mathrm{N}, \mathrm{P}$ and $\mathrm{K}$ foliar needle contents. Release from soil of inorganic nutrients, particularly of $\mathrm{N}$ immediately following clearcut harvesting of white spruce (Picea glauca) in Alaska (Gordon and Van Cleve 1983) offers a possible explanation. Similar responses may prevail in the southern boreal forest as well. In a carefully logged clearcut upland black spruce site in Quebec, a minimum $2^{\circ} \mathrm{C}$ increase in temperature during the growing season in the organic layer was observed (Smith et al. 2000). Smith et al. (1998) further found the black spruce microbial community in organic layers responded to increased temperature by mineralizing organic $\mathrm{N}$. Thus, nutrient availability in Claybelt wetlands likely was increased due to higher soil temperatures and soil disturbance and possibly greater nutrient leaching from post-harvest slash (Teng et al. 1996) associated with heavy harvest (Del Rio and Berg 1979, Van Cleve et al. 1981).

Fertilization appears to alleviate nutrient deficiencies that exist in black spruce wetland systems. Fertilization with N, NP, NK, and NPK significantly increased the foliar content of $\mathrm{N}$ in the first year (Table 4). The most effective fertilizer treatment was NP, which tripled foliar N concentration at the end of the first season (219\% higher than the control) and produced the maximum foliar contents of both $\mathrm{N}$ and $\mathrm{P}$ throughout the entire experiment (Table 4). Similarly, NP addition improved foliar P status but the magnitude of the effect, in relative terms $(81 \%)$, was less than that of N. In 1997, NP fertilization had significantly increased the foliar content of $\mathrm{K}, \mathrm{Mg}$, and $\mathrm{Ca}$ over all other treatments, proving to be the most effective fertilizer treatment. Nutrient supply in the peat soil was sufficient for suppling the $\mathrm{Ca}$ and $\mathrm{Mg}$ requirements (Table 4) for increased spruce growth. Further, the Ca supply on P-treated soils was augmented by the $\mathrm{Ca}$ in superphosphate fertilizer.

The results of this research indicate that stimulation of tree growth, associated with increased nutrient absorption by released black spruce advance regeneration, may have accelerated re-establishment of the black spruce component, and thus stabilized the ecosystem. Further study is needed to investigate whether mechanical harvesting by HARP also accelerated nutrient absorption and growth of other vegetation such as broadleaved shrub species. On the negative side, mechanical harvesting

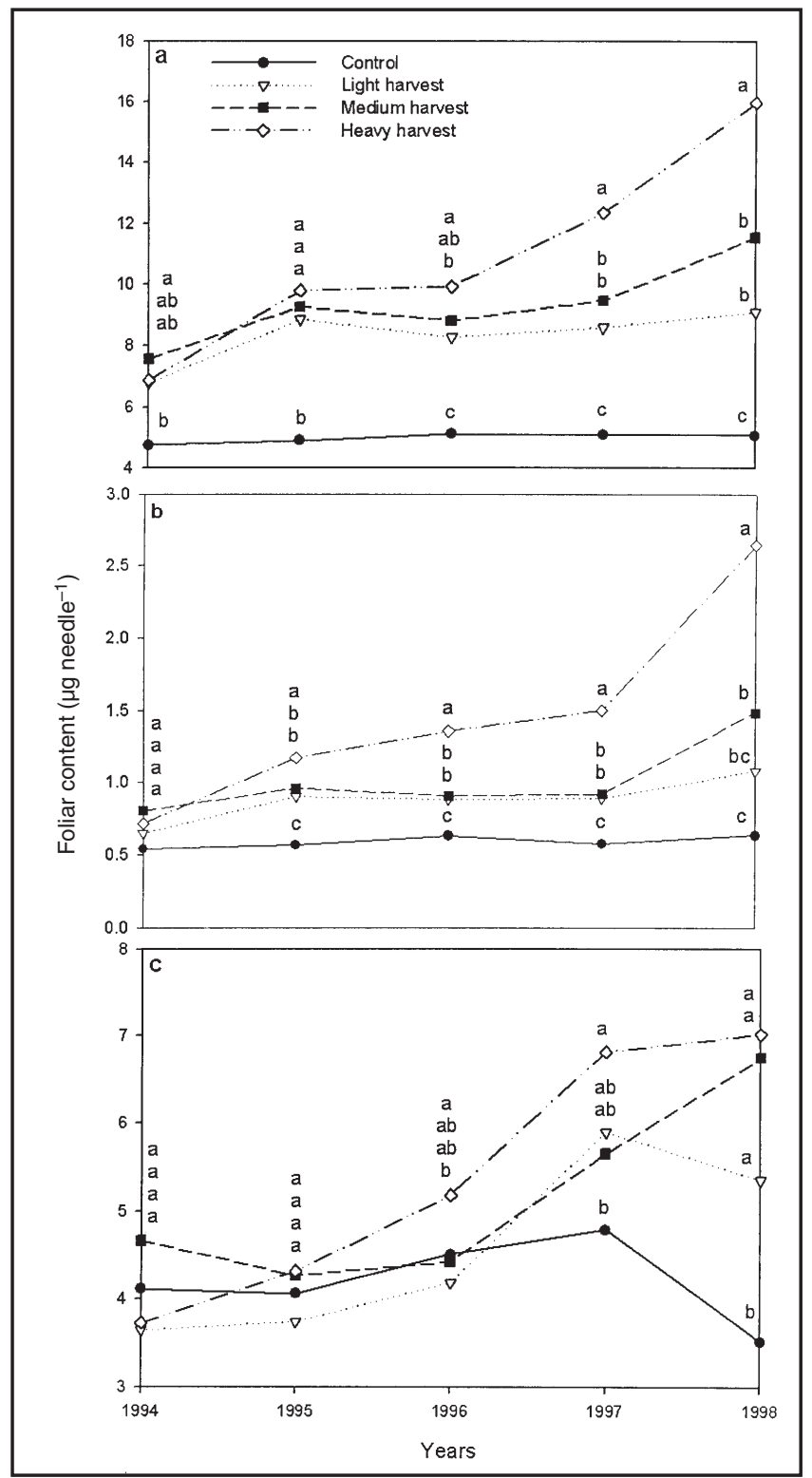

Fig. 3. Nutrient content ( $\mu \mathrm{g} /$ needle) of (a) nitrogen; (b) phosphorus; (c) potassium in black spruce foliage from advance regeneration after different intensities of harvest in 1994. Data points with the same letter are not significantly different $(\mathrm{p}<0.05 ; \mathrm{n}=4)$.

has caused soil compaction (Brais and Camiré 1998), exposure of displaced, poorly decomposed Sphagnum peat, and waterfilled depressions (Brumelis and Carleton 1988, 1989) on wetland sites similar to those in this study. Such soil disturbance may promote the establishment of unwanted fast-growing "weedy" species such as alders, sedges, and grasses (Groot 1987). Longer-term investigations that follow the growth and nutrition dynamics of the plant-soil system of HARP stands are needed for further verification of the advantages of HARP.

\section{Diagnosis for Nutrient Deficiencies and Interactions}

Harvest treatments reduced shading and thereby increased the photosynthesis capacity of understory black spruce advance regeneration. The effect of soil resources (nutrients, moisture) availability on seedling growth increases as ambient light 
Table 4. Changes by treatment and sampling year in N, P, K, Ca and Mg needle content ( $\mu \mathrm{g}$ needle ${ }^{-1}$ ) of black spruce understory advance regeneration released and fertilized in the spring of 1994. Means followed by same letter in column are not significantly different $(\mathbf{p}<0.05 ; \mathbf{n}=4)$

\begin{tabular}{|c|c|c|c|c|c|c|}
\hline Nutrient & Treatment & 1994 & 1995 & 1996 & 1997 & 1998 \\
\hline $\mathrm{N}$ & $\begin{array}{l}\text { Control } \\
\mathrm{N} \\
\mathrm{P} \\
\mathrm{K} \\
\mathrm{NP} \\
\mathrm{PK} \\
\mathrm{NK} \\
\text { NPK }\end{array}$ & $\begin{array}{c}4.76 \mathrm{a} \\
11.39 \mathrm{bc} \\
8.47 \mathrm{ab} \\
5.12 \mathrm{a} \\
15.22 \mathrm{c} \\
5.36 \mathrm{a} \\
14.92 \mathrm{c} \\
12.39 \mathrm{bc}\end{array}$ & $\begin{array}{c}8.32 \mathrm{a} \\
11.72 \mathrm{abc} \\
11.47 \mathrm{abc} \\
8.69 \mathrm{ab} \\
12.82 \mathrm{c} \\
12.18 \mathrm{c} \\
11.76 \mathrm{bc} \\
10.82 \mathrm{abc}\end{array}$ & $\begin{array}{l}7.06 \mathrm{a} \\
7.17 \mathrm{a} \\
7.33 \mathrm{a} \\
7.90 \mathrm{a} \\
8.65 \mathrm{a} \\
7.60 \mathrm{a} \\
6.77 \mathrm{a} \\
7.30 \mathrm{a}\end{array}$ & $\begin{array}{l}7.96 \mathrm{a} \\
7.00 \mathrm{a} \\
7.45 \mathrm{a} \\
7.25 \mathrm{a} \\
9.05 \mathrm{a} \\
8.16 \mathrm{a} \\
7.21 \mathrm{a} \\
6.42 \mathrm{a}\end{array}$ & $\begin{array}{c}8.30 \mathrm{a} \\
11.16 \mathrm{ab} \\
13.01 \mathrm{ab} \\
9.99 \mathrm{ab} \\
13.09 \mathrm{~b} \\
10.60 \mathrm{ab} \\
10.56 \mathrm{ab} \\
9.81 \mathrm{ab}\end{array}$ \\
\hline $\mathrm{P}$ & $\begin{array}{l}\text { Control } \\
\mathrm{N} \\
\mathrm{P} \\
\mathrm{K} \\
\mathrm{NP} \\
\mathrm{PK} \\
\mathrm{NK} \\
\mathrm{NPK}\end{array}$ & $\begin{array}{l}0.72 \mathrm{a} \\
0.78 \mathrm{a} \\
0.76 \mathrm{a} \\
0.59 \mathrm{a} \\
1.30 \mathrm{~b} \\
0.88 \mathrm{ab} \\
0.77 \mathrm{a} \\
1.02 \mathrm{ab}\end{array}$ & $\begin{array}{l}0.97 \mathrm{a} \\
0.84 \mathrm{a} \\
1.96 \mathrm{c} \\
0.87 \mathrm{a} \\
1.79 \mathrm{bc} \\
0.79 \mathrm{a} \\
1.98 \mathrm{c} \\
1.47 \mathrm{~b}\end{array}$ & $\begin{array}{l}1.07 \mathrm{~b} \\
0.77 \mathrm{a} \\
1.56 \mathrm{c} \\
1.06 \mathrm{~b} \\
1.69 \mathrm{c} \\
1.54 \mathrm{c} \\
0.71 \mathrm{a} \\
1.28 \mathrm{~b}\end{array}$ & $\begin{array}{l}1.60 \mathrm{abc} \\
0.86 \mathrm{a} \\
1.36 \mathrm{abc} \\
0.85 \mathrm{a} \\
1.60 \mathrm{c} \\
1.43 \mathrm{bc} \\
0.92 \mathrm{ab} \\
1.59 \mathrm{c}\end{array}$ & $\begin{array}{l}1.46 \mathrm{a} \\
1.66 \mathrm{ab} \\
2.46 \mathrm{~b} \\
1.43 \mathrm{a} \\
2.52 \mathrm{~b} \\
2.33 \mathrm{ab} \\
1.55 \mathrm{ab} \\
2.25 \mathrm{ab}\end{array}$ \\
\hline K & $\begin{array}{l}\text { Control } \\
\mathrm{N} \\
\mathrm{P} \\
\mathrm{K} \\
\mathrm{NP} \\
\mathrm{PK} \\
\mathrm{NK} \\
\mathrm{NPK}\end{array}$ & $\begin{array}{l}3.73 \mathrm{a} \\
3.33 \mathrm{a} \\
3.01 \mathrm{a} \\
4.20 \mathrm{a} \\
3.83 \mathrm{a} \\
3.87 \mathrm{a} \\
3.72 \mathrm{a} \\
4.26 \mathrm{a}\end{array}$ & $\begin{array}{l}4.24 \mathrm{abc} \\
3.56 \mathrm{a} \\
5.14 \mathrm{bd} \\
3.89 \mathrm{ac} \\
4.79 \mathrm{bcd} \\
5.56 \mathrm{~d} \\
3.43 \mathrm{a} \\
4.34 \mathrm{abc}\end{array}$ & $\begin{array}{l}3.69 \mathrm{bc} \\
2.63 \mathrm{a} \\
3.87 \mathrm{bc} \\
4.15 \mathrm{c} \\
3.74 \mathrm{bc} \\
4.00 \mathrm{bc} \\
2.44 \mathrm{a} \\
3.23 \mathrm{ab}\end{array}$ & $\begin{array}{l}5.41 \mathrm{ab} \\
4.69 \mathrm{ab} \\
5.14 \mathrm{ab} \\
4.80 \mathrm{ab} \\
5.98 \mathrm{~b} \\
5.41 \mathrm{ab} \\
4.18 \mathrm{a} \\
4.66 \mathrm{ab}\end{array}$ & $\begin{array}{l}6.02 \mathrm{a} \\
5.90 \mathrm{a} \\
7.94 \mathrm{a} \\
6.14 \mathrm{a} \\
7.86 \mathrm{a} \\
7.26 \mathrm{a} \\
5.94 \mathrm{a} \\
7.13 \mathrm{a}\end{array}$ \\
\hline $\mathrm{Ca}$ & $\begin{array}{l}\text { Control } \\
\mathrm{N} \\
\mathrm{P} \\
\mathrm{K} \\
\mathrm{NP} \\
\mathrm{PK} \\
\mathrm{NK} \\
\mathrm{NPK}\end{array}$ & $\begin{array}{l}3.66 \mathrm{ab} \\
3.55 \mathrm{ab} \\
2.72 \mathrm{a} \\
3.04 \mathrm{ab} \\
5.44 \mathrm{c} \\
3.74 \mathrm{ab} \\
4.30 \mathrm{bc} \\
3.59 \mathrm{ab}\end{array}$ & $\begin{array}{l}3.88 \mathrm{a} \\
3.37 \mathrm{a} \\
6.00 \mathrm{c} \\
3.62 \mathrm{a} \\
6.23 \mathrm{c} \\
5.76 \mathrm{bc} \\
3.22 \mathrm{a} \\
4.40 \mathrm{ab}\end{array}$ & $\begin{array}{l}3.78 \mathrm{bcd} \\
3.03 \mathrm{ab} \\
4.66 \mathrm{de} \\
4.22 \mathrm{~cd} \\
5.33 \mathrm{e} \\
4.31 \mathrm{~cd} \\
2.81 \mathrm{a} \\
3.38 \mathrm{abc}\end{array}$ & $\begin{array}{l}4.13 \mathrm{a} \\
4.15 \mathrm{a} \\
5.56 \mathrm{ab} \\
4.68 \mathrm{ab} \\
6.13 \mathrm{~b} \\
5.25 \mathrm{ab} \\
4.34 \mathrm{a} \\
4.32 \mathrm{a}\end{array}$ & $\begin{array}{l}4.97 \mathrm{a} \\
5.54 \mathrm{ab} \\
7.02 \mathrm{bc} \\
5.56 \mathrm{ab} \\
7.36 \mathrm{c} \\
5.84 \mathrm{abc} \\
5.51 \mathrm{ab} \\
5.11 \mathrm{a}\end{array}$ \\
\hline $\mathrm{Mg}$ & $\begin{array}{l}\text { Control } \\
\mathrm{N} \\
\mathrm{P} \\
\mathrm{K} \\
\mathrm{NP} \\
\mathrm{PK} \\
\mathrm{NK} \\
\mathrm{NPK}\end{array}$ & $\begin{array}{l}0.57 \mathrm{a} \\
0.72 \mathrm{ab} \\
0.47 \mathrm{a} \\
0.54 \mathrm{a} \\
0.89 \mathrm{~b} \\
0.54 \mathrm{a} \\
0.70 \mathrm{ab} \\
0.70 \mathrm{ab}\end{array}$ & $\begin{array}{l}0.77 \mathrm{a} \\
0.76 \mathrm{a} \\
1.11 \mathrm{~b} \\
0.78 \mathrm{a} \\
1.08 \mathrm{~b} \\
1.05 \mathrm{~b} \\
0.72 \mathrm{a} \\
0.94 \mathrm{ab}\end{array}$ & $\begin{array}{l}0.76 a b \\
0.75 a b \\
0.85 b c \\
0.88 b c \\
0.97 c \\
0.87 b c \\
0.63 a \\
0.81 a b c\end{array}$ & $\begin{array}{l}0.77 \mathrm{a} \\
0.94 \mathrm{abc} \\
0.93 \mathrm{abc} \\
0.86 \mathrm{ab} \\
1.14 \mathrm{c} \\
0.92 \mathrm{abc} \\
0.88 \mathrm{ab} \\
1.05 \mathrm{bc}\end{array}$ & $\begin{array}{l}0.75 \mathrm{a} \\
1.02 \mathrm{a} \\
1.02 \mathrm{a} \\
0.82 \mathrm{a} \\
1.07 \mathrm{a} \\
0.90 \mathrm{a} \\
0.89 \mathrm{a} \\
0.95 \mathrm{a}\end{array}$ \\
\hline
\end{tabular}

levels increase from those beneath intact canopies (Canham et al. 1996). The overall light requirement decreases with tree size (Messier et al. 1999), thereby allowing other environmental conditions (nutrients, moisture) to have a greater influence on understory spruce growth.

Vector analysis is a nutritional diagnostic approach by which three growth parameters, nutrient concentration, nutrient uptake and mass, for all treatments can be simultaneously evaluated and compared graphically in a single nomogram, allowing for detection and isolation of dilution effects, nutrient deficiency and toxicity, and element interactions independent of predetermined critical levels or ratios (Haase and Rose 1995). Interpretation of the results of vector diagnosis (Fig. 4) showed that enhanced current needle biomass and leader length from the harvest treatments could mainly be attributed to considerably improved foliar $\mathrm{N}$ nutrition, indicated by the increased $\mathrm{N}$ status on the logged treatments (i.e., consistent shifts

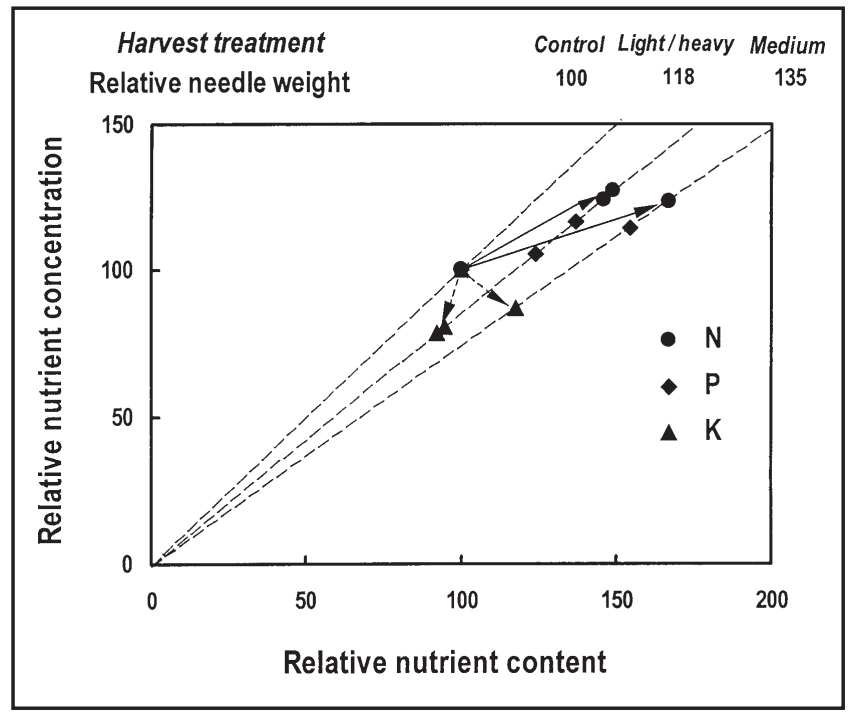

Fig. 4. Relative response to intensity of harvest of understory black spruce advance regeneration foliage in dry weight, nutrient concentration and nutrient content of needles in 1994.

to the right of the diagonal by arrows for $\mathrm{N}$ ). The greatest immediate post-harvest increase in needle mass was observed after medium harvest. Understory spruce on medium harvest plots may have been under less competitive stress for nutrients than spruce on plots dominated by Alnus-herb poor (ES12) vegetation, because medium harvest plots supported a richer flora (ES 13; Alnus- herb rich), prior to harvest. Vector analysis indicates that growth of black spruce advance regeneration was primarily limited by $\mathrm{N}$ availability. Our conclusion is consistent with previous studies (Van Cleve et al. 1990, Paquin et al. 1998, McLaughlin et al. 2000) indicating N limitation constrained black spruce growth when cold, wet and acidic conditions in boreal forests reduce plant litter decomposition by soil microorganisms.

Results (Table 2) from the fertilization experiment further confirmed that $\mathrm{N}$ was deficient, since the largest needle weight was associated with enhanced $\mathrm{N}$ status when $\mathrm{N}$ was applied (Fig. 5a) or a somewhat lesser $\mathrm{N}$ response with addition of $\mathrm{P}$; but $\mathrm{K}$ alone had no such effect. When $\mathrm{N}$ was applied with $\mathrm{P}$ or PK (Fig. 5b), needle biomass further increased noticeably with NP interactions being most significant (Table 2). The results were similar to those reported by Munson and Timmer (1989).

Potassium in needles from the released treatments was diluted (Fig. 4) by the end of the first growing season. Addition of K slightly $(11 \%)$ increased foliar K concentration in the first season without stimulating tree growth (Table 3), which probably indicates that $\mathrm{K}$ supply for black spruce growing on the site was adequate. McLaren and Jeglum (1998) also found $\mathrm{K}$ levels to be adequate in mature black spruce forest on similar site conditions.

\section{Conclusions}

Release by careful logging significantly improved nutrient status and stimulated growth of black spruce advance regeneration in wetland forest, over the seven-year study period. The heavy HARP treatment resulted in the greatest increase in needle weight, attributed to improved foliar status of $\mathrm{N}$ and $\mathrm{P}$. The stimulation of height growth by HARP heavy harvest treatment 


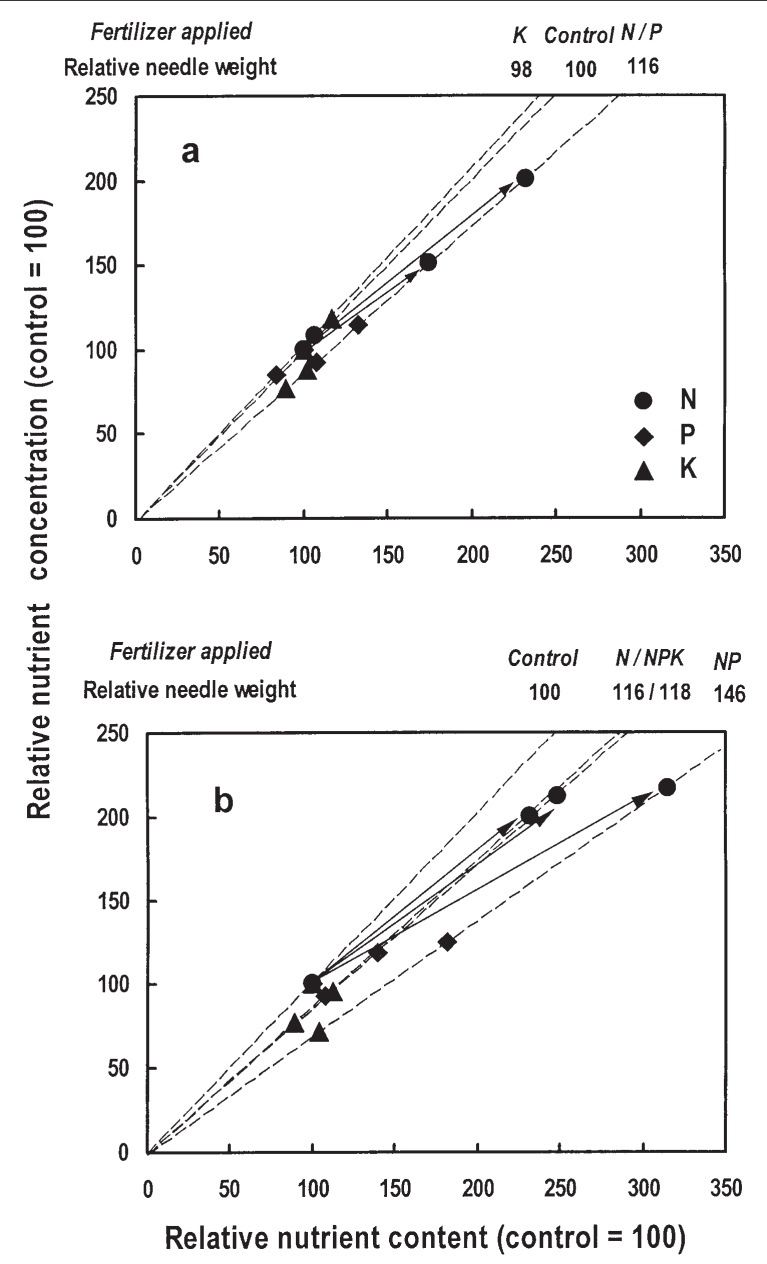

Fig. 5. Relative response of understory black spruce advance regeneration foliage in dry weight, nutrient concentration and nutrient content in 1994 to (a) N, P, or K fertilization and (b) N, NP, or NPK fertilization in heavy-harvest plots.

became statistically significant compared to light and medium treatments in the sixth and seventh year after release. Therefore, in terms of growth and nutritional response, the heavy treatment was clearly the most beneficial for early advance regeneration growth. Nitrogen and, secondly, $\mathrm{P}$ were the primary limiting nutrients, since $\mathrm{N}$ and $\mathrm{P}$ addition resulted in the most positive significant nutritional and growth response. Foliar K concentration was diluted on the harvested plots, but addition of $\mathrm{K}$ fertilizer failed to promote spruce growth any further. Spruce growth after release was therefore enhanced by increased absorption of nutrients, especially of $\mathrm{N}$ and $\mathrm{P}$. The underlying mechanisms of nutritional improvement are being investigated and will be reported in follow-up papers.

\section{Acknowledgements}

We thank Tyson Hardiman, Laura Hawdon, Linda Irwin, Wayne Johns, Keith Jones, Pat Kibee, Don Kurylo, Johanna Curry, Jo Ramakers, Doug Tribe and numerous students for technical assistance. Comments on an earlier draft of the manuscript by Ian Morrison and Victor Timmer and two anonymous referees are also gratefully acknowledged. Partners involved in the project were the Abitibi Consolidate Company of Canada., Iroquois Falls Division and the Forest Engineering Research Institute (FERIC). Financial support was provided by the Lake Abitibi Model Forest.

\section{References}

Anon. 1996. The Lake Abitibi Model Forest Workplan, 1996-1997. Canadian Forest Service, ON. 125 p.

Atmospheric Environment Service. 1982a. Canadian Climate Normals (1951-80). Vol.2. Temperature. Dep. Environ., Downsview, ON. 186 p.

Atmospheric Environment Service. 1982b. Canadian Climate Normals. (1951-80). Vol. 3. Precipitation. Dep. Environ., Downsview, ON. 602 p.

Bhatti, J.S., N.W. Foster and P.W. Hazlett. 1998. Fine root biomass and nutrient content in a black spruce peat soil with and without alder. Can. J. Soil Sci. 78: 163-169.

Brais, S. and C. Camiré. 1998. Soil compaction induced by careful logging in the claybelt region of northwestern Quebec (Canada). Can. J. Soil. Sci. 78: 197-206.

Brumelis, G. and T.J. Carleton. 1988. The vegetation of postlogged black spruce lowlands in central Canada. I. Trees and tall shrubs. Can. J. For. Res. 18: 1470-1478.

Brumelis, G. and T.J. Carleton. 1989. The vegetation of post-logged black spruce lowlands in central Canada. II. Understorey vegetation. J. Appl. Ecol. 26: 321-339.

Canham, C.D., A.R. Berkowitz, V.R. Kelly, G.M. Lovett, S.V. Ollinger and J. Schnurr. 1996. Biomass allocation and multiple resource limitation in tree seedlings. Can. J. For. Res. 26: 1521-1530.

Del Rio, El, and A.B. Berg. 1979. Growth of Douglas-fir reproduction in the shade of a managed forest. Res. Pap. 40. Forest Research Laboratory, Oregon State Univ. Press, Corvallis, OR. 452 p.

Doucet, R. et J. Boily. 1986. Croissance en hauteur compareé de marcottes et de plants à raciness nues d'épinette noire, ainsi que de plants de pin gris. Can. J. For. Res. 16: 1365-1368.

Gordon, A.M. and K. Van Cleve. 1983. Seasonal patterns of nitrogen mineralization following harvesting in white spruce forests of interior Alaska. In R.W. Wein, R.R. Riewe and I.R. Methven (eds.). Resources and Dynamics of the Boreal Zone: Proceedings of a Conference Held at Thunder Bay, ON., Aug. 1982. pp. 119-130. Ottawa. Assoc. Can. Univ. North. Stud.

Groot, A. 1987. Silviculture consequences of forest harvesting on peatlands: Site damage and slash conditions. Gov. Can., Can. For. Serv., Sault Ste. Marie, Ontario. Inf. Rep. O-X-384. 20 p.

Groot, A. 1995. Harvesting method affects survival of black spruce advance growth. North. J. Appl. For. 12: 8-11.

Haase, D.L. and R. Rose. 1995. Vector Analysis and its use for interpreting plant nutrient shifts in response to silvicultural treatments. For. Sci. 41: 54-66.

MacDonell, M.R. and A. Groot. 1996. Uneven-aged silviculture for peatland second-growth black spruce: Biological feasibility. Nat. Res. Can., Can. For. Serv., Sault Ste. Marie ON. NODA/NFP Tech. Rep. 36.14 p.

MacDonell, M.R. and A. Groot. 1997. Harvesting peatland black spruce: Impacts on advance growth and site disturbance. For. Chron.73: 249-255.

McCaughey, W.W. and W.C. Schmidt. 1982. Understory tree release following harvest cutting in spruce-fir forests of the Intermountain West. USDA For. Serv. Res. Pap. INT-285, Intermt. Forest and Range Experiment Station, Ogden, Utah. 19 p.

McLaughlin, J.W., M.R. Gale, M.F. Jurgensen and C.C. Trettin. 2000. Soil organic matter and nitrogen cycling in response to harvesting, mechanical site preparation, and fertilization in a wetland with a mineral substrate. For. Ecol. Manage. 129: 7-23.

McLaren, B.E. and J.K. Jeglum. 1998. Black spruce growth and foliar nutrient responses to drainage and fertilization: Wally Creek, Ontario. For. Chron. 74: 106-115. 
Messier, C., R. Doucet, J-C Ruel, Y. Claveau, C. Kelly, and M.J. Lechowicz. 1999. Functional ecology of advance regeneration in relation to light in boreal forests. Can. J. For. Res. 29: 812-823. Morin, H. and R. Gagnon. 1992. Comparative growth and yield of layer- and seed-origin black spruce (Picea mariana) stands in Quebec. Can. J. For. Res. 22: 465-473.

Morrison, I.K. 1991. Ten-year growth response to fertilizers by semimature black spruce and spruce-poplar mixedwoods near Kapuskasing, Ontario. For. Chron. 67: 27-32.

Munson, A.D. and V.R. Timmer. 1989. Site-specific growth and nutrition of planted Picea mariana in the Ontario Clay Belt. II Effects of nitrogen fertilizer. Can. J. For. Res. 19: 171-178.

Paquin, R. et R. Doucet. 1992. Productivité de pessières noires boréales régénérées par marcottage à la suite de vieilles coupes totales au Québec. Can. J. For. Res. 22: 601-612.

Paquin, R., H.A. Margolis and R. Doucet. 1998. Nutrient status and growth of black spruce layers and planted seedlings in response to nutrient addition in the boreal forest of Quebec. Can. J. For. Res. 28: 729-736.

Paquin, R., H.A. Margolis, R.Doucet and M.R. Coyea. 1999. Comparison of growth and physiology of layers and naturally established seedlings of black spruce in a boreal cutover in Quebec. Can. J. For. Res. 29: 1-8.

Pothier, D., R. Doucet and J. Boily. 1995. The effect of advance regeneration height on future yield of black spruce stands. Can. J. For. Res. 25: 536-544.

SAS Institute. 1985. SAS user's guide:Statistics. SAS Inst., Inc. Cary, NC.

Smith, C.K., M.R. Coyea and A.D. Munson. 2000. Soil carbon, nitrogen and phosphorus stocks and dynamics under disturbed black spruce forests. Ecol. Appl. 10: 775-788.

Smith, C.K., A.D. Munson and M.R. Coyea. 1998. Nitrogen and phosphorus release from humus and mineral soil under black spruce in central Quebec. Soil Biol. Biochem. 30: 1491-1500.
Taylor, K.C., R.W. Arnup, B.G. Merchant, W.J. Parton and J. Nieppola. 2000. A field guide to forest ecosystems of northeastern Ontario, $2^{\text {nd }}$ ed. Nest Field Guide FG-001. Ontario Ministry of Natural Resources.

Teng, Y., N.W. Foster, P. Hazlett and I.K. Morrison. 1996. Nutrient removals associated with harvesting peatland black spruce forest. In C.C. Trettin, M.F. Jurgensen, D.F. Grigal, M.R. Gale and J.K. Jeglum (eds.). Northern Forested Wetlands: Ecology and Management. pp. 341-352. CRC Press, Boca Raton, FL.

Timmer, V.R. 1991. Interpretation of seedling analysis and visual symptoms. In R.Van Den Driessche (ed.). Mineral Nutrition of Conifer Seedlings. pp. 113-134. CRC Press, Boca Raton, FL.

Van Cleve, K., R. Barney and R. Schlentner. 1981. Evidence of temperature control of production and nutrient cycling in two interior Alaska black spruce ecosystems. Can. J. For. Res. 11: 258-273. Van Cleve, K., W.C. Oechel and J.L. Hom. 1990. Response of black spruce (Picea mariana) ecosystems to soil temperature modification in interior Alaska. Can. J. For. Res. 20: 1530-1535.

Watt, R.F. 1967. Growth of black spruce stands after fertilization treatments based on foliar analysis. Proc. Soc. Amer. For. 1966: 85-88. Weetman, G.F., H.H. Krause, E. Koller and J.-M. Veilleux. 1987. Interprovincial Forest Fertilization trials: 5- and 10-year results. For. Chron. 63: 184-192.

Weetman, G.F. and R. Fournier. 1982. Graphical diagnoses of lodgepole pine response to fertilization. Soil. Sci. Soc. Am. J. 46: 1280-1289.

Wells, E.D. 1991. Effects of refertilization of an 18-year-old Japanese Larch (Larix leptolepis) plantation in western Newfoundland, Canada. In J.K. Jeglum and R.P. Overend (eds.). Proceedings of Symposium '89: Peat and Peatlands Diversification and Innovation, V.1 - Peatland Forestry. pp. 129-137. The Canadian Society for Peat and Peatlands. 